\title{
Upaya Meningkatkan Kemampuan Guru Dalam Penggunaan Metode Pembelajaran Melalui Supervisi Klinis di SD Negeri 7 Setia Bakti Tahun Pelajaran 2021
}

\author{
Nurmala, S.Pd.SD \\ SD Negeri 7 Setia Bakti
}

\begin{abstract}
Abstrak
Berdasarkan hasil pengamatan terhadap pelaksanaan supervisi klinis, diperoleh catatan 1. Guru sudah menguasai seluruh indikator yang dinilai, dengan hasil yang "sangat memuaskan". 2. Kemampuan guru dalam menerapkan metode juga memberikan efek positif terhadap siswa berupa peningkatan motivasi dan keaktifan yang selanjutnya menjadi nilai tambah guna meningkatkan prestasi belajar siswa. 3. Metode pembelajaran yang digunakan sudah sesuai dengan RPP yang disusun. Guru sudah memilih metode yang tepat dan sesuai dengan tujuan pembelajaran. Mengacu hasil pengamatan terhadap kemampuan guru kelas IV dari siklus I hanya mendapat nilai ratarata 2.55 meningkat menjadi 3,67 di siklus II, sementara kelas V dari sebelumnya pada siklus I hanya mendapat nilai rata-rata 2,67 berubah menjadi 3,67 pada siklus II dan kelas VI pada siklus I hanya mendapat rata-rata sama dengan kelas V yaitu 2,67 berubah menjadi 3,50, dengan predikat semua pada siklus II"sangat memuaskan".
\end{abstract}

Kata kunci : Kemampuan Guru dalam penggunaan metode Supervisi Klinis

\section{PENDAHULUAN}

Undang-Undang RI Nomor 20 Tahun 2003, tentang Sisdiknas Bab XI Pasal 39 ayat (1), dijelaskan tenaga kependidikan bertugas melaksanakan administrasi, pengelolaan, pengembangan, dan pelayanan teknis untuk menunjang proses pendidikan dan satuan pendidikan.

Guru memiliki posisi yang sangat penting dan menentukan keberhasilan pendidikan. Guru berada pada lini paling depan dalam keterlaksanaan proses pembelajaran di sekolah. Guru merupakan orang yang paling bertanggung jawab atas kualitas dan kebermaknaan proses pembelajaran di dalam kelas. Oleh karena itu, kinerja guru sangat berpengaruh terhadap keberhasilan sebuah proses pembelajaran.

Dalam kaitan dengan proses belajar mengajar hendaknya guru dapat mengarahkan dan membimbing siswa untuk aktif dalam kegiatan belajar mengajar sehingga tercipta suatu interaksi yang baik antara guru dengan siswa maupun siswa dengan siswa. Hal ini senada juga ditulis Madri M dan Rosmawati (2004: 274), bahwa terjadinya proses pembelajaran itu ditandai dengan dua hal yaitu : (1) siswa menunjukkan keaktifan, seperti tampak dalam jumlah curahan waktu untuk melaksanakan tugas ajar, (2) terjadi perubahan perilaku yang selaras dengan tujuan pengajaran yang diharapkan.

Pada kenyataannya dari hasil temuan di lapangan masih banyak guru yang belum mampu menerapkan metode-metode pembelajaran dengan baik. Kondisi tersebut juga terjadi di SD Negeri 7 Setia Bakti Kecamatan Setia Bakti Kabupaten Aceh Jaya. Dari 10 (Sepuluh) guru, 3 (Tiga) orang diantaranya selalu menggunakan metode pembelajaran dengan metode ceramah, tanya jawab, diskusi dan diakhiri dengan pemberian tugas. Pemberian materi juga lebih terpusat pada guru. Kemampuan guru 
dalam mengembangkan strategi pembelajaran melalui pemilihan metode, media, alat peraga, maupun sumber belajar belum optimal. Dengan kondisi demikian, jika dibiarkan maka akan menghambat proses pembelajaran dimana hasil belajar tidak akan dicapai dengan maksimal.

Berdasarkan uraian di atas maka penulis tertarik untuk mengadakan Penelitian Tindakan Sekolah dengan judul "Upaya Meningkatkan Kemampuan Guru dalam Penggunaan Metode Pembelajaran Melalui Supervisi Klinis di SD Negeri 7 Setia Bakti Kecamatan Setia Bakti Kabupaten Aceh Jaya Tahun Pelajaran 2020/2021”.

\section{Tujuan Penelitian}

Tujuan yang ingin dicapai dalam penelitian ini adalah: untuk mengetahui upaya peningkatan kemampuan guru dalam penggunaan metode pembelajaran melalui supervisi klinis.

\section{KAJIAN PUSTAKA}

\section{Kemampuan Guru SD dalam Kegiatan Belajar Mengajar}

Proses belajar mengajar merupakan kegiatan aktif siswa dalam membangun makna atau pemahaman. Dengan demikian, guru perlu memberikan dorongan kepada siswa untuk menggunakan otoritasnya dalam membangun gagasan. Tanggung jawab untuk menciptakan situasi yang mendorong prakarsa, motivasi, dan tanggung jawab siswa untuk belajar sepanjang hayat (Depdiknas, 2002: 1).

Dalam proses belajar mengajar menggambarkan adanya satu kesatuan yang tidak terpisahkan antara siswa yang belajar dengan guru yang mengajar, antara kedua kegiatan ini terjadi interaksi yang sangat menunjang. Kemampuan sering disebut dengan kompetensi. Menurut Abdul Majid (2005: 5-6) kompetensi adalah seperangkat tindakan inteligen penuh tanggung jawab yang harus dimiliki seseorang sebagai syarat untuk dianggap mampu melaksanakan tugas-tugas dalam bidang pekerjaan tertentu. Sifat inteligen harus ditunjukkan sebagai kemahiran, ketepatan dan keberhasilan bertindak. Sifat tanggung jawab harus ditunjukkan sebagai kebenaran tindak baik dipandang dari sudut ilmu pengetahuan, teknologi maupun etika.

\section{Metode Pembelajaran}

Metode mengajar adalah cara yang dipergunakan guru dalam mengadakan hubungan dengan siswa pada saat berlangsungnya pembelajaran (Nana Sudjana, 2005: 76). Metode yang ideal dalam belajar sebagaimana dikemukakan oleh Dewey (Samuel Smith, 1986: 260) memiliki ciri: 1. Murid harus benar-benar tertarik pada kegiatan, 2. Pengalaman atau pekerjaan yang edukatif ia harus menemukan dan memecahkan kesukaran atau masalah, 3. Mengumpulkan data-data melalui ingatan pemikiran dan pengalaman pribadi atau penelitian, 4. Menentukan cara pemecahan kesukaran atau masalah, 5. Mencoba cara terbaik untuk memecahkan sesuatu melalui penerapan dalam pengalaman, percobaan atau kehidupan sehari-hari.

\section{Penerapan Metode dalam Kegiatan Pembelajaran}

Pembelajaran bahasa diarahan pada upaya mempertajam kepekaan perasaan siswa, kepekaan sosial. Kepekaan sosial ini akan memperkaya strategi komunikasi. Siswa tidak hanya diharapkan mampu memahami informasi yang disampaikan secara lugas atau secara langsung, melainkan juga yang disampaikan secara terselubung atau tidak langsung. 
Karena itu, dalam kegiatan belajar mengajar, menurut Dra Roestiyah (dalam Syaiful Bahri Djamarah dan Aswan Zain, 2006: 74), guru harus memiliki strategi agar anak didik dapat belajar secara efektif dan efisien, mengenai pada tujuan yang diharapkan. Salah satu langkah untuk memiliki strategi itu adalah harus mengajar. Dengan demikian, metode mengajar adalah strategi pengajaran sebagai alat untuk mencapai tujuan yang diharapkan.

\section{Pemilihan dan Penentuan Metode}

Titik sentral yang harus dicapai oleh setiap kegiatan belajar mengajar adalah tercapainya tujuan pengajaran. Guru sebagai salah satu sumber belajar berkewajiban menyediakan lingkungan belajar yang kreatif bagi kegiatan belajar anak didik di kelas.

Salah satu kegiatan yang harus guru lakukan adalah melakukan pemilihan dan penentuan metode yang bagaimana yang akan dipilih untuk mencapai tujuan pengajaran (Syaiful Bahri Djamarah dan Aswan Zain, 2006: 77). Pemilihan dan penentuan metode ini didasari adanya metode-metode tertentu yang tidak bisa dipakai untuk mencapai tujuan tertentu.

\section{Supervisi Klinis}

Supervisi adalah usaha dari pertugas-petugas sekolah dalam memimpin guruguru dan petugas-petugas lainnya dalam memperbaiki pengajaran, termasuk menstimulasi, menyeleksi pertumbuhan jabatan dan perkembangan guru-guru serta merevisi tujuan-tujuan pendidikan, bahan pengajaran atau metode serta evaluasi pengajaran (Piet A. Sahertian, dkk, 2000: 17).

Supervisi klinis adalah bentuk supervisi yang difokuskan pada peningkatan mengajar dengan melalui siklus yang sistematik, dalam perencanaan, pengamatan serta analisis yang intensif dan cermat tentang penampilan mengajar yang nyata, serta bertujuan mengadakan perubahan dengan cara yang rasional (Piet A. Sahertian, 2008: 36).

\section{METODE PENELITIAN}

\section{Tempat dan Waktu Penelitian}

Penelitian ini dilaksanakan di SD Negeri 7 Setia Bakti Kecamatan Setia Bakti Kabupaten Aceh Jaya. Penelitian ini dilaksanakan pada tanggal 4 Februari 2021 - 3 Maret 2021

\section{Subyek Penelitian}

Subyek yang diteliti pada pelaksanaan Penelitian Tindakan Sekolah ini, adalah sebagai berikut: kepala sekolah (dirinya sendiri), guru kelas IV, V, dan VI yaitu : Guru kelas IV (Sdri. Laila Dimyati, S.Pd), guru kelas V (Sdri. Yusnidar, S.Pd), dan guru kelas VI (Sdri. Maryamah, S.Pd.SD), dengan jumlah siswa kelas IV 26 siswa, kelas V 30 siswa, dan kelas VI 26 siswa.

\section{Teknik Pengumpulan Data}

Teknik yang digunakan untuk mengumpulkan data meliputi observasi, wawancara, dan dokumentasi. 


\section{Teknik Analisis Data}

Teknik analisis data dilakukan dengan melakukan analisis SWOT, yang terdiri dari unsur-unsur S-Strength (kekuatan), W-Weaknesses (kelemahan), O-Opportuniy (kesempatan), T-Threat (ancaman). Empat hal tersebut dilihat dari sudut kepala sekolah yang melaksanakan dan guru yang dikenai tindakan (Suharsimi Arikunto, 2008: 7).

\section{HASIL PENELITIAN DAN PEMBAHASAN Kegiatan Siklus I}

Pelaksanaan penelitian tindakan sekolah ini dilaksanakan dengan tujuan untuk meningkatkan kemampuan guru dalam penggunaan metode pembelajaran melalui supervisi klinis. Tahapan-tahapan yang diterapkan untuk mencapai tujuan yang diharapkan meliputi:

1. Tahap perencanaan

2. Tahap pelaksanaan

3. Tahap pengamatan dan evaluasi

4. Tahap refleksi

Berikut ini tahap-tahap pelaksanaan penelitian tindakan sekolah untuk meningkatkan kemampuan guru dalam penggunaan metode pembelajaran pada guru kelas IV, V, dan VI SD Negeri 7 Setia Bakti Kecamatan Setia Bakti Kabupaten Aceh Jaya.

\section{Perencanaan}

Berdasarkan hasil supervisi awal yang dilaksanakan pada saat kunjungan kelas di kelas IV, V, dan VI SD Negeri 7 Setia Bakti Kecamatan Setia Bakti Kabupaten Aceh Jaya, ditemukan permasalahan sebagai berikut:

a. Pembelajaran terpusat kepada guru

- Metode yang digunakan belum sesuai dengan tujuan pembelajaran

- Pembinaan dalam menetapkan metode yang tepat dan sesuai dengan tujuan pembelajaran belum diterapkan dengan baik oleh guru.

- Melalui refleksi terhadap hasil supervisi awal, peneliti melakukan diskusi dengan guru-guru kelas IV, V, dan VI serta guru pengamat untuk memperoleh kesepakatan cara meningkatkan kemampuan guru dalam menggunakan metode pembelajaran.

Sebagai pendukung pelaksanaan supervisi pada siklus I, peneliti mempersiapkan perencanaan yang disesuaikan dengan kondisi yang ada. Berikut ini perencanaan yang disusun untuk melaksanakan supervisi pada siklus I:

a. Guru

- Mempersiapkan RPP sesuai dengan mata pelajaran.

- Mempersiapkan lembar informasi tentang supervisi

- Mempersiapkan kriteria RPP yang tepat

- Mempersiapkan kondisi pelaksanaan belajar mengajar untuk mengimplementasikan RPP dalam kegiatan pembelajaran.

b. Pengamat :

- Mempersiapkan lembar pelaksanaan supervisi

- Mempersiapkan lembar observasi

- Mempersiapkan lembar wawancara

- Mempersiapkan penilaian

\section{Pelaksanaan}

a. Pelaksanaan Supervisi Klinis di Kelas IV 
Sesuai dengan kesepakatan, pelaksanaan supervisi klinis pada guru kelas IV (Sdri. Laila Dimyati, S.Pd) pada tanggal 06 Februari tahun 2021, dengan tujuan melakukan pengamatan terhadap kemampuan guru dalam menggunakan metode pembelajaran. Pada pelaksanaan kegiatan supervisi klinis di kelas IV, peneliti melakukan supervisi terhadap kemampuan guru dalam menggunakan metode pembelajaran yang berhubungan dengan materi bahasa Indonesia, yaitu:

Standar Kompetensi :

4. Mengungkapkan pikiran, perasaan dan informasi secara tertulis dalam bentuk percakapan, petunjuk, cerita dan surat

Kompetensi Dasar

4.1. Melengkapi bagian cerita yang hilang (rumpang) dengan menggunakan $\mathrm{kata} / \mathrm{kalimat}$ yang tepat sehingga menjadi cerita yang padu. Indikator :

1. Mampu melengkapi cerita bagian awal, tengah, dan akhir dengan kata yang tepat sehingga menjadi kalimat padu.

2. Menentukan judul yang sesuai.

Tujuan Pembelajaran :

1. Siswa dapat melengkapi cerita dengan memperhatikan hubungan antara makna kalimat yang satu dengan kalimat lainnya.

2. Siswa dapat menentukan judul yang sesuai berdasarkan gambar seri.

Pelaksanaan supervisi terhadap kemampuan guru menerapkan metode pembelajaran dilakukan sejak kegiatan awal sampai kegiatan akhir pelajaran bahasa Indonesia.

b. Pelaksanaan Supervisi Klinis di Kelas V

Pada pelaksanaan kegiatan supervisi klinis di kelas V, Sdri. Yusnidar, S.Pd, guru melakukan presentasi terhadap kemampuan guru dalam menggunakan metode pembelajaran yang berhubungan dengan materi Bahasa Indonesia. Pelaksanaan supervisi klinis terhadap kemampuan guru dalam menggunakan metode pembelajaran bahasa Indonesia pada tanggal 09 Februari 2021, dengan perincian sebagai berikut:

Standar Kompetensi :

4. Mengungkapkan pikiran, perasaan, informasi, dan pengalaman secara tertulis dalam bentuk karangan, surat undangan, dan dialog tertulis.

Kompetensi Dasar

4.1 Menulis karangan berdasarkan pengalaman dengan memperhatikan pilihan kata dan penggunaan ejaan.

Indikator :

1. Mengembangkan ide pokok

2. Mengembangkan paragraf

3. Menyusun karangan cerita

Tujuan Pembelajaran :

1. Siswa dapat mengembangkan ide pokok dalam membuat karangan cerita yang sesuai dengan pengalamannya sendiri melalui bantuan media gambar bingkai.

2. Siswa dapat mengarang cerita secara lebih mudah dengan menggunakan pilihan kata yang tepat atau sesuai, susunan kalimat yang runtut dengan memperhatikan penggunaan ejaan yang benar.

Pelaksanaan supervisi klinis dilakukan sejak awal kegiatan pembelajaran sampai pada kegiatan akhir. 
c. Pelaksanaan Supervisi Klinis di Kelas VI

Pelaksanaan kegiatan supervise klinis di kelas VI, Sdri. Maryamah, S.Pd.SD, guru melakukan presentasi terhadap kemampuan guru menggunakan metode pembelajaran pada mata pelajaran matematika. Kegiatan supervisi klinis pada guru kelas VI dilaksanakan pada tanggal 12 Februari 2021, dalam materi matematika.

Standar Kompetensi :

2. Menggunakan pengukuran volume per waktu dalam pemecahan masalah. Kompetensi Dasar :

Mengenal satuan debit Indikator:

1. Siswa dapat menyebutkan satuan volume Pelaksanaan supervisi klinis dilakukan sejak awal kegiatan pembelajaran sampai pada kegiatan akhir.

\section{Pengamatan dan Evaluasi}

Pengamatan dan Evaluasi terhadap pelaksanaan pembelajaran di kelas IV

a. Hasil Pengamatan

Melakukan pengamatan terhadap guru dalam pembelajaran

Pelaksanaan pengamatan terhadap guru dilaksanakan selama pelaksanaan kegiatan pembelajaran yang meliputi kegiatan awal, kegiatan inti, dan kegiatan akhir. Kegiatan pembelajaran yang terdiri dari kegiatan awal, kegiatan inti dan kegiatan akhir dilaksanakan dengan baik. Guru melakukan supervisi tentang bagaimana cara guru mengelola kelas sehingga kegiatan belajar benar-benar berjalan dengan efektif.

Mengamati metode pembelajaran yang digunakan

Pengamatan metode pembelajaran difokuskan pada kemampuan guru dalam memilih metode pembelajaran, dengan indikator penilaian yang ditetapkan. Dari hasil pengamatan terhadap kemampuan guru dalam menggunakan metode pembelajaran pada pelaksanaan pembelajaran dalam materi bahasa Indonesia dengan tujuan agar siswa dapat melengkapi cerita dengan memperhatikan hubungan antara makna kalimat yang satu dengan kalimat lainnya dan siswa dapat menentukan judul yang sesuai berdasarkan gambar seri hasilnya masih dalam kategori "kurang" dengan nilai 2,55 karena berada dalam interval score yaitu 2,38-2,77.

b. Evaluasi

Mengacu pada hasil supervisi klinis untuk meningkatkan kemampuan guru dalam menggunakan metode pembelajaran, setelah dilakukan kunjungan kelas untuk mengetahui kemampuan guru dalam menggunakan metode maka dapat diperoleh catatan sebagai berikut:

- Indikator yang sudah dikuasai

- Kesesuaian antara metode dengan tujuan pembelajaran

- Metode dapat melibatkan siswa aktif dalam pembelajaran

- Metode yang digunakan dapat meningkatkan hasil belajar siswa

- Indikator yang belum dikuasai

- Kesesuaian metode dengan materi; disini guru sudah menerapkan beberapa metode agar kegiatan pembelajaran tidak terpusat pada guru dan siswa diarahkan untuk lebih aktif namun metode yang digunakan belum sesuai dengan materi. Maksudnya, metode tersebut tidak bisa membawa siswa lebih memahami materi yang diajarkan. 
- Metode belum memotivasi belajar siswa,

- Metode belum mengefektifkan kegiatan pembelajaran

Dari indikator yang belum dikuasai, maka diperlukan suatu metode yang bisa melibatkan siswa secara aktif dalam kegiatan pembelajaran dan membawa siswa lebih mudah dalam memahami materi.

Metode pembelajaran yang digunakan sudah sesuai dengan RPP yang disusun namun metode yang diterapkan belum optimal. Guru perlu memilih metode yang tepat dan sesuai dengan tujuan pembelajaran, pengembangan kemampuan berbahasa. Beberapa metode yang dapat diterapkan antara lain; pendekatan keterampilan proses, metode kontekstual, metode pendekatan terpadu dan sebagainya.

Pengamatan terhadap pelaksanaan pembelajaran di kelas V

a. Hasil Pengamatan

Melakukan pengamatan terhadap guru dalam pembelajaran

Kegiatan pengamatan di kelas V dilakukan saat guru melaksanakan kegiatan pembelajaran dalam materi Bahasa Indonesia. Pada saat guru melaksanakan kegiatan pembelajaran, guru membuka pelajaran dengan baik, melakukan apersepsi kemudian memotivasi anak. Guru sekilas menjelaskan materi yang akan dibahas. Pada kegiatan inti, guru melakukan eksplorasi, elaborasi dan konfirmasi. Kegiatan penutup dilakukan dengan melakukan kesimpulan terhadap pembelajaran, melakukan evaluasi dan tindak lanjut.

Mengamati metode pembelajaran yang digunakan

Hasil pengamatan terhadap metode pembelajaran yang digunakan guru dan hasil pengamatannya terhadap kemampuan guru kelas $\mathrm{V}$ dalam menggunakan metode pembelajaran pada pelaksanaan pembelajaran dalam materi bahasa Indonesia dengan tujuan : (1) siswa dapat mengembangkan ide pokok dalam membuat karangan cerita yang sesuai dengan pengalamannya sendiri melalui bantuan media gambar bingkai, dan (2) siswa dapat mengarang cerita secara lebih mudah dengan menggunakan pilihan kata yang tepat atau sesuai, susunan kalimat yang runtut dengan memperhatikan ejaan yang benar, kemampuan guru dalam menggunakan metode pembelajaran masih "kurang", dengan nilai rata-rata 2,67.

b. Evaluasi

Berdasarkan hasil pengamatan terhadap pelaksanaan supervisi klinis, diperoleh catatan sebagai berikut:

- Indikator yang sudah dikuasai

- Kesesuaian antara metode dengan tujuan pembelajaran

- Metode dapat memotivasi belajar siswa

- Metode dapat melibatkan siswa dalam pembelajaran

- Metode dapat meningkatkan hasil belajar siswa

- Indikator yang belum dikuasai

- Kesesuaian metode dengan materi

- Metode dapat mengefektifkan pembelajaran

Dari metode yang belum dikuasai, maka diperlukan adanya sifat terbuka dari guru tentang latar belakang permasalahan yang ada sehingga dapat dicari solusi terbaik agar metode pembelajaran yang diterapkan lebih maksimal.

Pengamatan terhadap pelaksanaan pembelajaran di kelas VI

a. Hasil Pengamatan

Melakukan pengamatan terhadap guru dalam pembelajaran 
Kegiatan pengamatan di kelas VI dilakukan saat guru melaksanakan kegiatan pembelajaran dalam materi matematika. Pada saat guru melaksanakan kegiatan pembelajaran, guru membuka pelajaran dengan baik, melakukan apersepsi kemudian memotivasi anak. Guru menjelaskan materi yang akan dibahas. Pada kegiatan inti, guru melakukan eksplorasi, elaborasi dan konfirmasi. Kegiatan penutup dilakukan dengan melakukan kesimpulan terhadap pembelajaran, melakukan evaluasi dan tindak lanjut.

Mengamati metode pembelajaran yang digunakan

Hasil pengamatan terhadap metode pembelajaran yang digunakan guru dan hasil pengamatannya terhadap kemampuan guru kelas VI dalam menggunakan metode pembelajaran pada pelaksanaan pembelajaran mata pelajaran matematika, kemampuan guru dalam menggunakan metode pembelajaran masih "kurang", dengan nilai rata-rata 2,67.

b. Evaluasi

Berdasarkan hasil pengamatan terhadap pelaksanaan supervisi klinis, diperoleh catatan sebagai berikut:

- Indikator yang sudah dikuasai

- Kesesuaian antara metode dengan tujuan pembelajaran

- Metode dapat melibatkan siswa dalam pembelajaran

- Metode dapat meningkatkan hasil belajar siswa

- Metode dapat mengefektifkan pembelajaran

- Indikator yang belum dikuasai

- Metode dapat memotivasi belajar siswa

- Kesesuaian metode dengan materi

Dari metode yang belum dikuasai, maka diperlukan adanya pembinaan secara individual agar kemampuan guru dapat ditingkatkan lagi sehingga pembelajaran dapat berhasil dengan maksimal.

Dalam kegiatan pembelajaran matematika di kelas VI, guru sudah menerapkan beberapa metode dengan asumsi dapat memaksimalkan hasil belajar siswa. Hal tersebut sudah efektif hanya perlu ditingkatkan lagi agar hasil belajar lebih maksimal.

\section{Refleksi}

Dari hasil pelaksanaan supervisi klinis pada upaya peningkatan kemampuan guru dalam menggunakan metode pembelajaran diketahui bahwa pada siklus I, guru sudah berusaha untuk meningkatkan kemampuannya dalam mengunakan metode pembelajaran.

Dari hasil observasi di kelas IV diketahui bahwa guru belum menerapkan seluruh metode yang terdapat dalam RPP. Selain itu pelaksanaan kegiatan pembelajaran juga masih membutuhkan metode yang tepat dan sesuai dengan tujuan pembelajaran, sehingga diperlukan adanya diskusi antara peneliti (kepala sekolah) dengan guru agar secara bersama-sama dapat mengatasi permasalahan yang ada.

Dari hasil observasi di kelas $\mathrm{V}$ diketahui bahwa metode konstruktivisme dan inquiri yang tercantum dalam RPP belum diterapkan ketika pelaksanaan pembelajaran. Dari temuan tersebut maka diperlukan suatu keterbukaan dari guru untuk mendiskusikan kealpaan tersebut dilatarbelakangi oleh masalah apa (misalnya: ketidakmampuan guru/keterbatasan waktu, dan sebagainya) sehingga dapat dipecahkan secara bersama-sama masalah yang ada. 
Dari hasil observasi di kelas VI guru juga belum menguasai seluruh indikator yang dinilai selama kegiatan supervisi klinis. Metode pembelajaran yang tercantum dalam RPP juga belum dioptimalkan karena ada satu metode yang terlewat yaitu tugas individual. Selain temuan-temuan tersebut, guru juga belum menerapkan metode yang baru yang benar-benar dapat melibatkan siswa secara aktif dalam kegiatan pembelajaran dan mampu memotivasi siswa untuk belajar matematika.

Dari temuan-temuan yang ada, maka diperlukan adanya upaya perbaikan untuk meninkatkan kemampuan guru dalam menggunakan metode pembelajaran sehingga penelitian tindakan sekolah dengan menerapkan pendekatan supervisi klinis harus dilanjutkan lagi pada siklus kedua.

\section{Kegiatan Siklus II}

Pelaksanaan penelitian tindakan sekolah pada siklus II ini dilaksanakan dengan tujuan untuk meningkatkan kemampuan guru dalam penggunaan metode pembelajaran melalui supervisi klinis. Tahapan-tahapan yang diterapkan untuk mencapai tujuan yang diharapkan meliputi:

1. Tahap perencanaan

2. Tahap pelaksanaan

3. Tahap pengamatan dan evaluasi

4. Tahap refleksi

Berikut ini tahap-tahap pelaksanaan penelitian tindakan sekolah untuk meningkatkan kemampuan guru dalam penggunaan metode pembelajaran pada guru kelas IV, V, dan VI SD Negeri 7 Setia Bakti Kecamatan Setia Bakti Kabupaten Aceh Jaya.

\section{Perencanaan}

Mengacu pada hasil supervisi pada siklus I di kelas IV, V, dan VI SD Negeri 7 Setia Bakti Kecamatan Setia Bakti Kabupaten Aceh Jaya, diketemukan permasalahan sebagai berikut:

a. Guru belum optimal dalam menggunakan metode pembelajaran.

b. Metode pembelajaran yang terdapat dalam RPP belum dioptimalkan penerapannya.

c. Guru belum berani menggunakan metode pembelajaran yang lebih variatif sehingga hanya terpusat pada diskusi, ceramah, tanya jawab, dan pemberian tugas.

Melalui refleksi terhadap hasil supervisi siklus I, peneliti melakukan diskusi dengan guru-guru kelas IV, V, dan VI serta guru pengamat untuk memperoleh kesepakatan cara meningkatkan kemampuan guru dalam menggunakan metode pembelajaran.

Sebagai pendukung pelaksanaan supervisi pada siklus II, peneliti mempersiapkan perencanaan yang disesuaikan dengan kondisi yang ada. Berikut ini perencanaan yang disusun untuk melaksanakan supervisi pada siklus II:

1. Guru

- Mempersiapkan RPP sesuai dengan mata pelajaran.

- Mempersiapkan lembar informasi tentang supervisi

- Mempersiapkan kriteria RPP yang tepat

- Mempersiapkan kondisi pelaksanaan belajar mengajar untuk mengimplementasikan RPP dalam kegiatan pembelajaran.

2. Pengamat

- Mempersiapkan lembar pelaksanaan supervisi 


\section{Pelaksanaan}

- Mempersiapkan lembar observasi

- Mempersiapkan lembar wawancara

- Mempersiapkan penilaian

Pelaksanaan Supervisi Klinis di Kelas IV

Pelaksanaan supervise klinis pada siklus II dilaksanakan tanggal 26 Februari 2021. Pada pelaksanaan kegiatan supervisi klinis di kelas IV, peneliti melakukan supervisi terhadap kemampuan guru dalam menggunakan metode pembelajaran mata pelajaran bahasa Indonesia, yaitu:

Standar Kompetensi :

4. Mengungkapkan pikiran, perasaan dan informasi secara tertulis dalam bentuk percakapan, petunjuk, cerita dan surat

Kompetensi Dasar

1.1. Melengkapi bagian cerita yang hilang (rumpang) dengan menggunakan $\mathrm{kata} / \mathrm{kalimat}$ yang tepat sehingga menjadi cerita yang padu.

\section{Indikator}

1. Mampu melengkapi cerita bagian awal, tengah, dan akhir dengan kata yang tepat sehingga menjadi kalimat padu.

2. Menentukan judul yang sesuai.

\section{Tujuan Pembelajaran}

1. Siswa dapat melengkapi cerita dengan memperhatikan hubungan antara makna kalimat yang satu dengan kalimat lainnya.

2. Siswa dapat menentukan judul yang sesuai berdasarkan gambar seri.

Pelaksanaan supervisi terhadap kemampuan guru menerapkan metode pembelajaran dilakukan sejak kegiatan awal sampai kegiatan akhir pelajaran bahasa Indonesia.

\section{Pelaksanaan Supervisi Klinis di Kelas V}

Pada pelaksanaan kegiatan supervisi klinis pada guru kelas $\mathrm{V}$ dilakukan pada tanggal 28 Februari 2021, pada mata pelajaran Bahasa Indonesia. Pelaksanaan supervisi klinis terhadap kemampuan guru dalam menggunakan metode pembelajaran pada materi bahasa Indonesia, dengan perincian sebagai berikut:

Standar Kompetensi :

4. Mengungkapkan pikiran, perasaan, informasi, dan pengalaman secara tertulis dalam bentuk karangan, surat undangan, dan dialog tertulis.

Kompetensi Dasar :

4.1 Menulis karangan berdasarkan pengalaman dengan memperhatikan pilihan kata dan penggunaan ejaan.

\section{Indikator :}

1. Mengembangkan ide pokok

2. Mengembangkan paragraf

3. Menyusun karangan cerita

Tujuan Pembelajaran :

1. Siswa dapat mengembangkan ide pokok dalam membuat karangan cerita yang sesuai dengan pengalamannya sendiri melalui bantuan media gambar bingkai. 
2. Siswa dapat mengarang cerita secara lebih mudah dengan menggunakan pilihan kata yang tepat atau sesuai, susunan kalimat yang runtut dengan memperhatikan penggunaan ejaan yang benar.

Pelaksanaan supervisi klinis dilakukan sejak awal kegiatan pembelajaran sampai pada kegiatan akhir.

\section{Pelaksanaan Supervisi Klinis di Kelas VI}

Pelaksanaan kegiatan supervise klinis terhadap upaya peningkatan kemampuan guru dalam menggunakan metode pembelajaran dilaksanakan pada tanggal 29 Februari 2021 dengan sampel pada pelaksanaan materi matematika.

Standar Kompetensi :

2. Menggunakan pengukuran volume per waktu dalam pemecahan masalah.

Kompetensi Dasar :

Mengenal satuan debit

Indikator:

1. Siswa dapat menyebutkan satuan volume

Pelaksanaan supervisi klinis dilakukan sejak awal kegiatan pembelajaran sampai pada kegiatan akhir.

\section{a. Pengamatan dan Evaluasi}

Pengamatan dan Evaluasi terhadap pelaksanaan pembelajaran di kelas IV

1. Hasil Pengamatan

Melakukan pengamatan terhadap guru dalam pembelajaran

Pelaksanaan pengamatan terhadap guru dilaksanakan selama pelaksanaan kegiatan pembelajaran yang meliputi kegiatan awal, kegiatan inti, dan kegiatan akhir, dengan mengamati pelaksanaan kegiatan pembelajaran. Hasil pengamatan tertuang dalam ceck list sebagai tolak ukur tingkat keberhasilan guru dalam melaksanakan kegiatan pembelajaran.

Mengamati metode pembelajaran yang digunakan

Pengamatan metode pembelajaran difokuskan pada kemampuan guru dalam memilih metode pembelajaran, dengan indikator penilaian yang ditetapkan. Dari hasil pengamatan terhadap kemampuan guru dalam menggunakan metode pembelajaran pada pelaksanaan pembelajaran mata pelajaran bahasa Indonesia dengan tujuan agar siswa dapat melengkapi cerita dengan memperhatikan hubungan antara makna kalimat yang satu dengan kalimat lainnya dan siswa dapat menentukan judul yang sesuai berdasarkan gambar seri hasilnya masih dalam kategori "sangat memuaskan" dengan nilai rata-rata 3,67 karena berada dalam interval score yaitu $2,78-3,27$.

2. Evaluasi

Mengacu pada hasil supervisi klinis untuk meningkatkan kemampuan guru dalam menggunakan metode pembelajaran, setelah dilakukan kunjungan kelas untuk mengetahui kemampuan guru dalam menggunakan metode maka dapat diperoleh catatan sebagai berikut:

a. Guru sudah menguasai seluruh indikator yang dinilai, dengan hasil yang "memuaskan".

b. Kemampuan guru dalam menerapkan metode juga memberikan efek positif terhadap siswa berupa peningkatan motivasi dan keaktifan yang 
selanjutnya menjadi nilai tambah guna meningkatkan prestasi belajar siswa.

c. Metode pembelajaran yang digunakan sudah sesuai dengan RPP yang disusun. Guru sudah memilih metode yang tepat dan sesuai dengan tujuan pembelajaran, pengembangan kemampuan berbahasa antara lain menerapkan metode CTL.

Pengamatan terhadap pelaksanaan pembelajaran di kelas $\mathrm{V}$

1. Hasil Pengamatan

Melakukan pengamatan terhadap guru dalam pembelajaran

Kegiatan pengamatan terhadap kemampuan guru kelas $\mathrm{V}$ dalam menggunakan metode pembelajaran dilaksanakan pada tanggal 26 Februari 2021. Pada saat guru melaksanakan kegiatan pembelajaran, guru membuka pelajaran dengan baik, melakukan apersepsi kemudian memotivasi anak. Guru sekilas menjelaskan materi yang akan dibahas. Pada kegiatan inti, guru melakukan eksplorasi, elaborasi dan konfirmasi. Kegiatan penutup dilakukan dengan melakukan kesimpulan terhadap pembelajaran, melakukan evaluasi dan tindak lanjut.

Mengamati metode pembelajaran yang digunakan

Hasil pengamatan terhadap metode pembelajaran yang digunakan guru dan hasil pengamatannya terhadap kemampuan guru kelas $\mathrm{V}$ dalam menggunakan metode pembelajaran pada pelaksanaan pembelajaran mata pelajaran bahasa Indonesia, sudah "sangat memuaskan" dengan nilai ratarata 3,67 .

2. Evaluasi

Berdasarkan hasil pengamatan terhadap pelaksanaan supervisi klinis, diperoleh catatan sebagai berikut:

a. Guru sudah menguasai seluruh indikator yang dinilai, dengan hasil yang "sangat memuaskan".

b. Kemampuan guru dalam menerapkan metode juga memberikan efek positif terhadap siswa berupa peningkatan motivasi dan keaktifan yang selanjutnya menjadi nilai tambah guna meningkatkan prestasi belajar siswa.

c. Metode pembelajaran yang digunakan sudah sesuai dengan RPP yang disusun. Guru sudah memilih metode yang tepat dan sesuai dengan tujuan pembelajaran.

Peningkatan kemampuan guru dalam menggunakan metode pembelajaran menunjukkan bahwa pelaksanaan supervisi klinis dengan memperhatikan aspek kebutuhan guru dan diskusi antara kepala sekolah dengan guru memberikan efek yang positif terhadap perkembangan kemampuan guru.

Pengamatan terhadap pelaksanaan pembelajaran di kelas VI

1. Hasil Pengamatan

Melakukan pengamatan terhadap guru dalam pembelajaran

Kegiatan pengamatan untuk mengetahui kemampuan guru kelas VI dalam menggunakan metode pembelajaran dilaksanakan pada tanggal 2829 Februari 2021. Hasil pengamatan menunjukkan bahwa guru sudah 
melakukan kegiatan pembelajaran dengan baik dengan mengacu pada RPP yang disusun berdasarkan Standar Isi dan Standar Proses.

Hasil pengamatan terhadap metode pembelajaran yang digunakan guru dan hasil pengamatan terhadap kemampuan guru kelas VI dalam menggunakan metode pembelajaran pada pelaksanaan pembelajaran mata pelajaran matematika hasilnya sudah "sangat memuaskan" dengan rata-rata skor 3,50.

2. Evaluasi

Berdasarkan hasil pengamatan terhadap pelaksanaan supervisi klinis, diperoleh catatan sebagai berikut:

Guru sudah menguasai seluruh indikator yang dinilai, dengan hasil yang "sangat memuaskan".

Kemampuan guru dalam menerapkan metode juga memberikan efek positif terhadap siswa berupa peningkatan motivasi dan keaktifan yang selanjutnya menjadi nilai tambah guna meningkatkan prestasi belajar siswa kelas VI yang akan menempuh ujian akhir.

Metode pembelajaran yang digunakan sudah sesuai dengan RPP yang disusun. Guru sudah memilih metode yang tepat dan sesuai dengan tujuan pembelajaran.

Peningkatan kemampuan guru dalam menggunakan metode pembelajaran menunjukkan bahwa pelaksanaan supervisi klinis dengan memperhatikan aspek kebutuhan guru dan diskusi antara kepala sekolah dengan guru memberikan efek yang positif terhadap perkembangan kemampuan guru dalam meningkatkan kemampuan menggunakan metode pembelajaran.

\section{d. Refleksi}

Dari hasil pelaksanaan supervisi klinis pada upaya peningkatan kemampuan guru dalam menggunakan metode pembelajaran diketahui bahwa pada siklus II, guru sudah berusaha untuk meningkatkan kemampuannya dalam mengunakan metode pembelajaran, dan hasilnya sangat memuaskan.

Dari hasil observasi di kelas IV diketahui bahwa guru sudah menerapkan seluruh metode yang terdapat dalam RPP. Selain itu pelaksanaan kegiatan pembelajaran juga sudah menerapkan fasiasi metode sehingga kegiatan pembelajaran yang dilaksanakan lebih maksimal.

Dari hasil observasi di kelas V diketahui bahwa kemampuan guru dalam menguasai metode pembelajaran sudah meninkat dengan hasil perolehan score "sangat memuaskan". Hal itu ditunjukkan dari kemampuan guru melakukan kegiatan pembelajaran dengan tepat dan menerapkan seluruh metode yang ada di RPP sehingga pembelajaran memperolehhasil yang maksimal.

Dari hasil observasi di kelas VI guru juga sudah mampu menguasai seluruh indikator yang dinilai selama kegiatan supervisi klinis. Metode pembelajaran yang tercantum dalam RPP juga sudah dioptimalkan karena ada satu metode yang terlewat yaitu tugas individual. Dari temuan-temuan yang ada, maka pelaksanaan penelitian tindakan sekolah dengan menerapkan supervisi klinis guna meningkatkan kemampuan guru dalam menggunakan alat peraga dapat diakhiri pada siklus II.

\section{Pembahasan}

Pelaksanaan supervisi klinis pada dasarnya difokuskan pada perbalikan pengajaran dengan melalui siklus yang sistematis dari tahap perencanaan, pengamatan, 
dan analisis intelektual yang intensif terhadap penampilan mengajar sebenarnya dengan tujuan mengadakan modifikasi rasional.

Berkaitan dengan pelaksanaan kegiatan supervisi klinis di SD Negeri 7 Setia Bakti, target yang diharapkan adalah kemampuan guru dalam menggunakan metode pembelajaran dengan asumsi bahwa melalui penerapan metode yang tepat maka proses ekplorasi, elaborasi dan konfirmasi dalam kegiatan inti pembelajaran dapat dioptimalkan sehingga prestasi belajar siswa menjadi meningkat.

Dasar pertimbangan pengembangan profesionalisme guru pada indikator tersebut karena guru merupakan ujung tombak dalam peningkatan kualitas pembelajaran dan penanam nilai-nilai dasar pada pendidikan sekolah dasar yang selanjutnya akan sangat bermanfaat bagi perkembangan anak didiknya di masa yang akan datang.

Dari hasil pelaksanaan supervisi klinis pada studi awal, siklus I, dan siklus II, dapat dijelaskan melalui grafik kemampuan menggunakan metode pembelajaran sebagai berikut:

\section{Rata-rata Kemampuan Guru dalam Menggunakan Metode Pembelajaran}

Kelas IV Kelas V Kelas VI

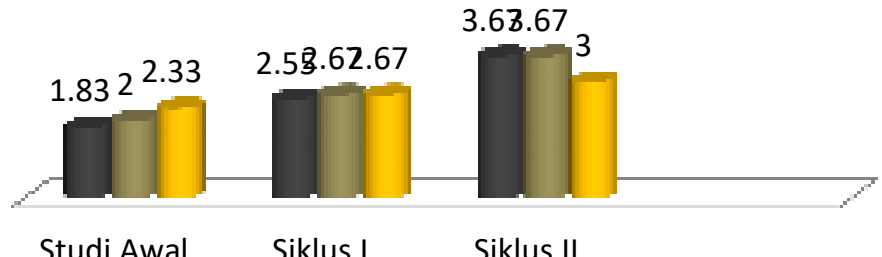

\section{Gambar. Persentase Kemampuan Guru Menguasai Indikator dalam RPP}

Melalui pencapaian tersebut, maka tujuan dari supervisi klinis yang antara lain membantu guru mengembangkan kompetensinya, dapat tercapai dengan optimal. Hal tersebut juga dikemukakan oleh guru setelah pelaksanaan observasi. Berkaitan dengan kemampuan guru dalam menggunakan metode pembelajaran, guru kelas IV (Sdri. Laila Dimyati, S.Pd) menyatakan sebagai berikut melalui latihan, bimbingan dan dukungan pada kegiatan supervisi kemampuan kami dalam menggunakan alat peraga menjadi lebih maksimal. (wawancara tanggal 26 Februari 2021).

Guru kelas V, (Sdri. Yusnidar, S.Pd), memberikan penyataan berkaitan dengan kemampuan dalam menggunakan metode pembalajaran beberapa indikator yang semula kurang kami pahami, saat ini sudah bisa dipahami dengan baik. Kami juga bisa menerapkan seluruh metode yang sudah tercatat dalam RPP. (wawancara tanggal 28 Februari 2021).

Dan guru kelas VI, Sdri, Maryamah, S.Pd.SD memberikan pernyataan tentang kemampuan menyusun RPP beberapa metode baru kami terapkan, dan hal tersebut ternyata hasilnya luar biasa terhadap peningkatan keaktifan dan motivasi siswa untuk belajar. Ini tentu sangat positif karena kelas VI merupakan masa-masa menjelang ujian nasional yang butuh kesungguhan siswa dalam memahami materi. (wawancara tanggal 29 Februari 2021).

Dari hasil wawancara tersebut, maka secara garis besar melalui kegiatan supervisi klinis diperoleh catatan sebagai berikut:

- Kemampuan guru dalam menggunakan metode pembelajaran meningkat. 
- Guru lebih menguasai indikator dalam penguasaan metode pembelajaran.

- Guru dapat memilih metode yang tepat dan sesuai dengan tujuan pembelajaran.

- Guru lebih terbuka saat mendapatkan permasalahan khususnya dalam penentuan metode pembelajaran.

\section{Kesimpulan}

Mengacu pada hasil penelitian tindakan sekolah melalui kegiatan pembinaan akademik, disimpulkan yaitu keberhasilan sebuah kegiatan pembelajaran dipengaruhi oleh banyak faktor, baik faktor yang dating dari guru, siswa, maupun kepala sekolah sebagai pemimpin di sekolah. Salah satu peranan kepala sekolah dalam kegiatan pembelajaran adalah melakukan upaya perbaikan pembelajaran guru dengan menerapkan pendekatan supervisi, diantaranya supervisi klinis. Metode pembelajaran merupakan salah satu komponen yang sangat mempengaruhi keberhasilan kegiatan belajar mengajar, karena di dalamnya memuat strategi agar anak didik dapat belajar secara efektif dan esifien. Peningkatan kemampuan guru dalam menggunakan metode pembelajaran melalui supervisi klinis merupakan salah satu solusi yang cukup efektif. Hal tersebut dapat dilihat dari hasil akhir penelitian dimana guru dapat menguasai indikator yang ada dalam menentukan metode pembelajaran dan mencari metode yang benar-benar tepat dan sesuai dengan tujuan pembelajaran serta kondisi lingkungan kelas dan lingkungan sekolah itu sendiri yang selanjutnya memberikan manfaat bagi peningkatan prestasi belajar siswa dan peningkatan mutu sekolah.

\section{DAFTAR PUSTAKA}

Abdul Majid, 2005. Perencanaan Pembelajaran. Bandung: Remaja Rosdakarya Arikunto, Suharsimi. 2008. Dasar-dasar Evaluasi Pendidikan. Jakarta : Bumi. Aksara Depdiknas, 2002. Kurikulum dan HAsil Belajar Kompetensi Dasar. Jakarta: Balitbangdiknas

Nana Sudjana, 2005. Strategi Pembelajaran. Bandung: Alfabeta

Madri M. dan Rosmawati 2004. Jurnal Pembelajaran, Desember. Vol. 27, No. 03, h. 274

Piet A. Sahertian, 2000. Konsep Dasar dan Teknik Supervisi Pendidikan Dalam Rangka Pengambangan Sumber Daya Manusia. Jakarta: Rineka Cipta

Samuel Smith, mengjarkan-matematika-sebuah-pemikiran.html diakses dari http://chamisah.blogspot.com

Syaiful Bahri Djamarah dan Aswan Zain, 2006. Strategi Belajar Mengajar. Jakarta: Rineka Cipta 